\title{
Effect of Temperature on the Process of the Hypersensitive Death of a Potato Plant Cell Infected by an Incompatible Race of Phytophthora infestans*
}

\author{
Kohei Tomiyama** \\ 富山宏平： 非親和性疫病菌レースの感染を受けたジャガィモ細胞の \\ 過敏感細胞死の過程に対する温度の影響
}

\begin{abstract}
The process of hypersensitive death of a potato cell infected by an incompatible race of Phytophthora infestans was observed by using a temperature controlled, inverted microscope. More precise observation than in previous experiments disclosed that the process of hypersensitive death of the cells consisted of at least two phases : cessation of protoplasmic streaming and then loss of stainability of vacuole with neutral red. The infected cell still maintained stainability with neutral red and could absorb it after the protoplasmic streaming stopped. After a while, the cell lost the stainability with neutral red. The effect of temperature on this process was investigated. The time elapsed from inoculation to the penetration was longer at $20 \mathrm{C}$ than at 25 and $30 \mathrm{C}$.

By extraporating the growth curve of the intracellular hyphae to 0 , length of the penetration was judged to finish 10-15 min before the hyphae become actually visible, so that the time required for hypersensitive cell death is longer than that estimated in prior experiments.

In $10-20 \%$ of the cut surface cells inoculated $18 \mathrm{hr}$ after cutting, protoplasmic streaming stopped about $30 \mathrm{~min}$ after penetration (at 20, 25 and $30 \mathrm{C}$ ) and in $50 \%$ of the cells protoplasmic streaming stopped about $37 \mathrm{~min}(20 \mathrm{C}) 40 \mathrm{~min}(25 \mathrm{C})$ and $45 \mathrm{~min}$ (30 C) after penetration. The cells seemed to lose their stainability with neutral red about $30 \mathrm{~min}(20 \mathrm{C}), 10 \mathrm{~min}(25 \mathrm{C})$ and $10 \mathrm{~min}(30 \mathrm{C})$ after protoplasmic streaming stopped.
\end{abstract}

(Received July 26, 1972)

\section{Introduction}

In previous papers13)6/7)8), the author reported on the time required for hypersensitive death of a potato-plant cell infected by an incompatible race of Phytophthora infestans. In the present experiments, the author tried to make more precise observation on the process of hypersensitive death by using a temperature-controlled inverted microscope. Moreover. the effect of temperature on the process was investigated.

\section{Materials and methods}

The potato cultivar "Rishiri" $\left(\mathrm{R}_{1}\right)$ and Phytophthora infestans race 0 was used as materials. The

* Cell physiological studies on resistance of potato plants to Phytophthora infestans (14)

** Hokkaido National Agricultural Experiment Station, Sapporo, Japan. 北海道農業試験場

Present address: Plant Pathology Laboratory, Faculty of Agriculture

Nagoya University. Nagoya, Japan. 名古屋大学農学部 
former is incompatible with the latter. Leaf petioles were cut longitudinally, and the cut surface were washed thoroughly with flowing water. They were held in a large wet Petri dish for $18 \mathrm{hr}$ and then inoculated with a zoospore suspension of Phytophthora infestans. The inoculated petioles were incubated in a large Petri dish at $18 \mathrm{C}$. Forty min after inoculation, the petioles were transfered to other dishes at $20 \pm 1 \mathrm{C}, 25 \pm 1 \mathrm{C}$ and $30 \pm 1 \mathrm{C}$. After an additional $30-40 \mathrm{~min}$, a leaf petiole was taken out from the dishes at intervals and microscopic sections were made with a razor. Observation of each section was finished within about $10 \mathrm{~min}$ to minimize the effect of sectioning and mounting in neutral red solution on the time process of hypersensitive cell death.

A Nikon inverted microscope model $M$ equipped with a plastic incubator was used. The air temperature in the incubator was automatically regulated. To maintain the sample at the same temperature as that of the incubator as far as possible, a heat absorbing filter was used in the light system of the microscope. The time required for the penetration of the host cell walls by the parasite was deduced from the curve obtained by plotting the percentages of the penetrated cells per total ones appressed by appressoria against time.

To relate the process of hypersensitive cell death to time, percentages of the cells in which protoplasmic streaming stopped upon infection and of those in which the vacuoles lost stainability with neutral red were plotted against time or the length of hyphae which were contained in those cells. Experiments were repeated seven times at each temperature. The values obtained were averaged.

Growth rates of the infecting hyphae in the cells were followed under the inverted microscope. The microscopic section was placed in a small drop of water on the slide glass without a cover glass to avoid oxygen shortage as far as possible. The appressoria infected the host cell in the manners as shown in figure 4 . Observation was made on the appressoria penetrating the cell in the manner shown in $\mathrm{C}$ or $\mathrm{D}$ in figure 4 , because in the cases of $\mathrm{A}$ or $\mathrm{B}$ it is difficult to observe the penetrating hyphae in an initial period. The distance from the rand of the appressorium to the top of the infecting hyphae was measured as the hyphal length as shown by a in Fig. 4. The length of hyphae was plotted against time and the curve obtained was extrapolated back to base line, assuming that the hyphae grew linearly. The point the curve cut the abscissa was taken as the time when the appressoria penetrated the host cell wall. Experiments were repeated eight times at each temperature.

\section{Results}

As reported in the previous papers ${ }^{6 / 7) 8}$, the time required for hypersensitive death of the cut surface cell of potatoes infected by an incompatible [race of Phytophthora infestans was distinctly shortened by ex-

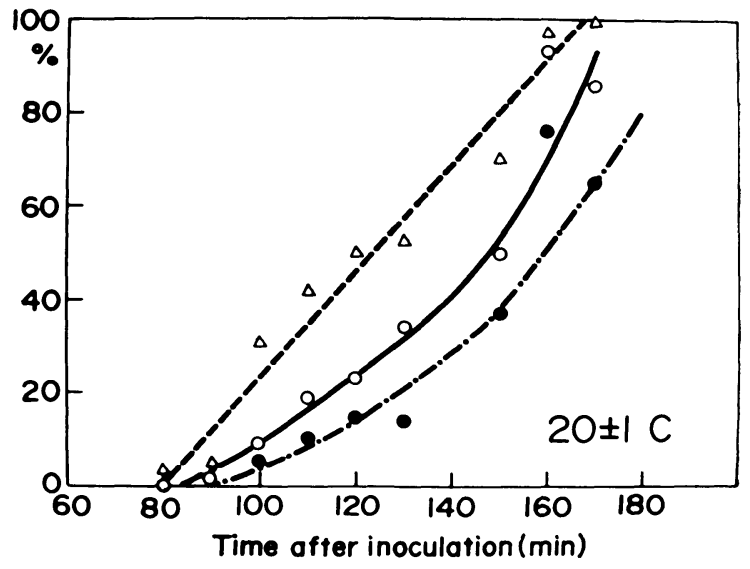

Fig. 1. The time from inoculation to penetration (triangle) of cell walls of the potato cells by $P$. infestans (race 0), to stop of protoplasmic streaming of the infected host cell (open circle) and to loss of stainability of the infected host cells with neutral red (filled circle). Percentages of the cells penetrated, of the cells in which protoplasmic streaming stopped and of those which have lost the stainability with neutral red are plotted against time. 
Table 1. Time elapsed from inoculation to penetration, from penetration to halt in protoplasmic streaming and from the halt in streaming to loss of stainability with neutral red. Calculated from the curves (as in Fig. 1.) obtained by plotting each phenomenon against time, using values at $50 \%$

\begin{tabular}{cccc}
\hline \hline Temperature & $\begin{array}{c}\text { From inoculation } \\
\text { to penetration } \\
(\mathrm{min})\end{array}$ & $\begin{array}{c}\text { From penetration } \\
\text { to stop of proto- } \\
\text { plasmic streaming } \\
\text { (min) }\end{array}$ & $\begin{array}{c}\text { From stop of protoplasmic } \\
\text { streaming to loss of } \\
\text { stainability with neutral red } \\
\text { (min) }\end{array}$ \\
\hline $20 \pm 1 \mathrm{C}$ & 120 & 25 & 10 \\
$25 \pm 1 \mathrm{C}$ & 95 & 10 & 10 \\
$30 \pm 1 \mathrm{C}$ & 90 & 10 & 10 \\
\hline
\end{tabular}

Table 2. Time required for the intracellular hyphae of Phytophthora infestans: race 0 to grow $1 \mu \mathrm{m}$ in length in the cut surface cells of potato leaf petioles

\begin{tabular}{cccc}
\hline \hline Temperature (C) & $20 \pm 1$ & $25 \pm 1$ & $30 \pm 1$ \\
\hline Max. & $8.7^{\min }$ & $\min$ & $\min$. \\
Min. & 6.7 & 10.4 & 10.0 \\
Average* & $7.8 \pm 0.6^{* *}$ & $7.9 \pm 2.0$ & $7.5 \pm 1.9$ \\
\hline
\end{tabular}

* Averages of 8 cases each.

** Standard deviation.

posing them to air for more than $5 \mathrm{hr}$ before inoculation. The first group of experiments was done with the surface cells of cut and then air exposed (for about $18 \mathrm{hr}$ ) tissue.

Examples of the curves obtained by plotting against time the percentages of cells penetrated, of cells in which protoplasmic streaming stopped and of cells which lost stainability with neutral red are shown in Fig. 1. The effect of temperature on the time elapsed from inoculation to penetration, from penetration to cessation of protoplasmic streaming and from the halt in streaming to loss of the stainability with neutral red were deduced from the curves (Table 1).

Curves obtained by plotting against the length of penetrating hyphae the percentages of the cells in which protoplasmic streaming stopped and of those which lost stainability with neutral red are shown in Fig. 2.

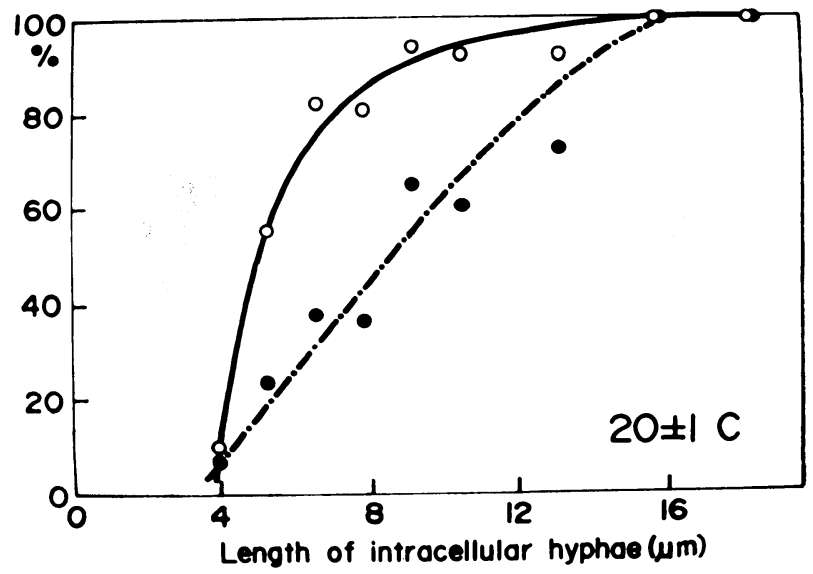

Fig. 2. Relation between percentage of the potato cells in which Protoplasmic streaming stopped by infection by 'the incompatible race 'of $P$. infestans (open circle) and those which have lost the stainability with neutral red (filled circle) and the length of the intracellular hyphae. 
Examples of the curves obtained by plotting the length of the intracellular hyphae against time are shown in Fig. 3. The infecting hyphae are usually spherical in an initial period, and then gradually protrude usual hyphae. In this spherical hyphal stage relatively accurate measurement can be done regardless of the direction of hyphal growth. Therefore effect of temperature on the growth rate were calculated from the growth curves within 4-5 $\mu \mathrm{m}$. (Table 2). There were no difference among the growth rates at different temperatures tested in an initial period of infection. By using averages of the growth rates of the hyphae, the intervals from penetration to stop of protoplasmic streaming and from stop of protoplasmic

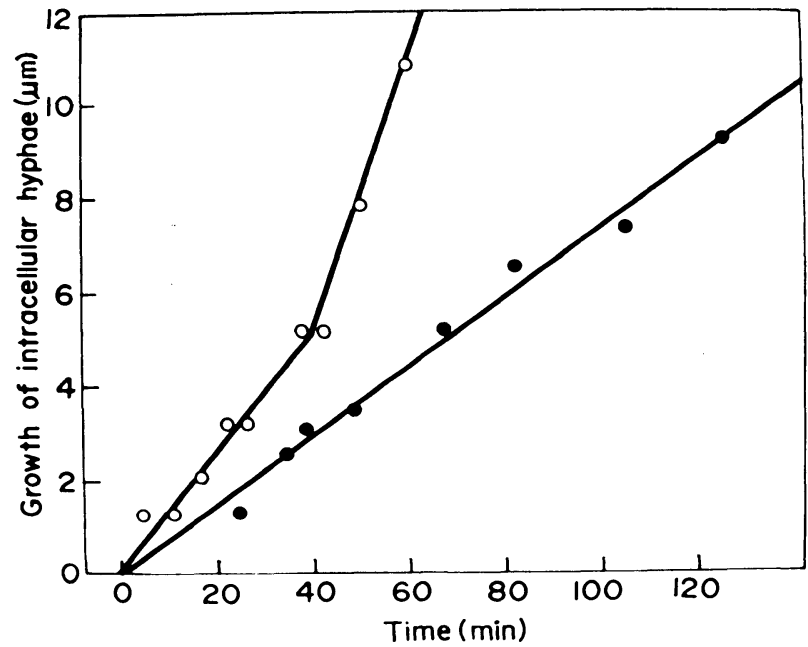

Fig. 3. Two different types of hyphal growth-rates of the $P$. infestans (race 0 ) in the potato cells. Closed and open circles do not indicate difference in experimental condition or treatment, but only the results from different series of observations. streaming to loss of stainability of the infected cell with neutral red was related to time (Tabel 3).

Table 3. Time elapsed from penetration to halt in protoplasmic streaming and from halt in protoplasmic streaming to loss of stainability with neutral red. Calculated from the curves obtained by plotting each phenomenon against the intracellular hyphal length (as in Fig. 2)

\begin{tabular}{|c|c|c|c|}
\hline \multirow[b]{2}{*}{ Temperature } & \multicolumn{2}{|c|}{$\begin{array}{l}\text { From penetration to stop of } \\
\text { protoplasmic streaming }\end{array}$} & \multirow{2}{*}{$\begin{array}{c}\text { From stop of protoplasmic } \\
\text { streaming to loss of stain- } \\
\text { ability with neutral red. } \\
\text { For } 50 \% \text { of the infected cells } \\
\text { (min) }\end{array}$} \\
\hline & $\begin{array}{c}\text { For } 10-20 \% \text { of } \\
\text { the infected } \\
\text { cells } \\
(\mathrm{min})\end{array}$ & $\begin{array}{l}\text { For } 50 \% \text { of } \\
\text { the infected } \\
\text { cells } \\
(\mathrm{min})\end{array}$ & \\
\hline $20 \pm 1$ & 30 & 37 & 30 \\
\hline $25 \pm 1$ & 30 & 40 & 10 \\
\hline $30 \pm 1$ & 30 & 45 & 10 \\
\hline
\end{tabular}

\section{Discussion}

The present experiments indicated that the vacuole of the host cell still maintained stainability with neutral red after the protoplasmic streaming stopped. In this stage, the cells seemed to be able to absorb neutral red, and to accumulate it. This phenomenon was clearly demonstrated in other experiments using micro-cinematography2).

After the stainability of vacuole with neutral red was lost, the appearance of the cell shows granular degeneration and it could not be plasmolyzed with hypertonic sucrose solution. The cells were apparently dead.

To know the time required for the process of hypersensitive death, it is necessary to measure 
the time when the protoplasmic streaming stops upon infection and also the time when the cells lose the stainability with neutral red. To do this, it is necessary to measure the exact time of penetration. In the previous reports1)3)45)6), the time of penetration was deduced from the curves obtained by plotting percentages of penetrated cells against time. However, in the present experiment, the author failed to discern penetrating hyphae less than about $1 \mu \mathrm{m}$ in length, and it may take about $8 \mathrm{~min}$ for the penetrating hyphae to reach $1 \mu \mathrm{m}$ assuming that the penetrating hyphae grow linearly with time just after penetration.

Moreover, if the penetration site is located in the central part of the appressorium (Fig. 4), it may take about $20 \mathrm{~min}$ to reach the minimum length of hypha which can be discerned by an observer as a penetration, since the radius of the appressorium was about $2 \mu \mathrm{m}$. More time may be necessary, if the appressorium is hidden by its mother encysted zoospore (Fig. 4). It may take about $45 \mathrm{~min}$ if the penetration occurs at the center of the mother zoospore.

In the present experiments in which measurment was made with the cases $C$ and D in Fig. 4, the time needed for penetration may be shorter than the true value by about $10-15$ $\min$ or so.

Taking these facts into consideration, the percentages of cell death were plotted against the length of penetrating hyphae to avoid the error as far as possible. The hyphal length was then converted into time by measuring growth rate of penetrating hyphae.
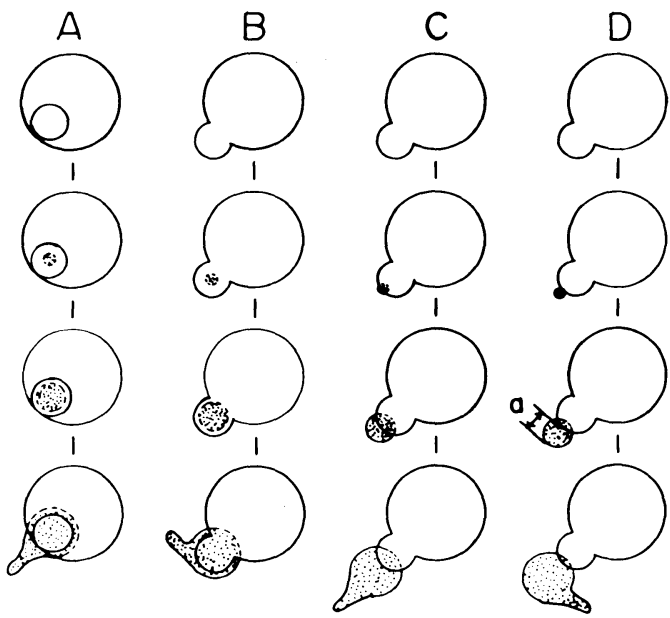

Fig. 4. Process of penetration of host cell wall by appressoria of Phytophthora infestans. The dotted portion indicates the hyphae which have penetrated the host cell wall. $\mathrm{A}, \mathrm{B}, \mathrm{C}$ and $\mathrm{D}$ indicates different types of the infection process. D-a indicates the methods to measure the length of hypha.

With the cut surface cells of the petioles inoculated about $18 \mathrm{hr}$ after cutting, it was concluded that protoplasmic streaming stopped in about $10-20 \%$ of the infected cells about 30 min after penetration (at 20,25 and $30 \mathrm{C}$ ) and in $50 \%$ of those within about $37 \mathrm{~min}(20 \mathrm{C}) 40 \mathrm{~min}(25 \mathrm{C})$ or $45 \mathrm{~min}$ $(30 \mathrm{C})$. The curves obtained by plotting against time the percentage of the cells in which these phenomena occurred were similar to those in the experiments reported previously1)3(4)5)6), if the time for penetration deduced from these curves is corrected by adding 10-15 min according to the former discussion. The time from the halt in protoplasmic streaming to loss of stainability with neutral red was about $30 \mathrm{~min}$ at $20 \pm 1 \mathrm{C}$, about $10 \mathrm{~min}$ at $25 \pm 1 \mathrm{C}$, and about $10 \mathrm{~min}$ at $30 \pm 1 \mathrm{C}$.

The time required for penetration of the cell wall by the parasite was apparently longer at $20 \pm 1 \mathrm{C}$ than $25 \pm 1 \mathrm{C}$ and $30 \pm 1 \mathrm{C}$.

\section{Literature cited}

1) Kitazawa, K. and Tomiyama, K. (1969). Phytopathol. Z. 66 : 317-324.

2) Kitazawa, K., Inagaki, H. and Tomiyama, K. (1971). Phytopath. Z. in press.

3) Tomiyama, K. (1956). Ann. Phytopath. Soc. Japan $20: 165-169$.

4) Tomiyama, K. (1957). Ibid. $22: 237-242$.

5) Tomiyama, K. (1957). Ibid. $22: 74-78$.

6) Tomiyama, K. (1960). Phytopathol. Z. $39:$ 134-148. 
7) Tomiyama, K. (1967). Ibid. 58: 367-378.

8) Tomiyama, K. (1970). In "Morphological and biochemical events in host-parasite interaction." Ed. by S. Akai and S. Ouchi, the U.S.-Japan Coop. Sci. Program. Phytopath. Soc. Japan.

\section{和文摘要}

非親和性疫病菌レースの感染を受けたジャガイモ細胞の

過敏感細胞死の過程に対する温度の影響

富山宏平

非親和性疫病菌レースの感染を受けたジャガイモ葉柄切断面細胞の過敏感細胞死の過程について, 温度調節 装置を借えたニコン倒立影微鏡を用いて観察を行なった。過敏感細胞死の過程は 2 相からなり，第 1 相は原形質 流動の停止であり，第 2 相は中性赤染色性のそら失である。原形質流動が停止した時点で液胞の中性赤染色性は なお保持されており，かつ新しく中性赤を吸収することができる。

これらの過敏感死の過程に要する時間に対する温度の影響を調べた。過敏感細胞死に要する時間を測定する 場合に貫入時間の測定が問題となるが貫入後の菌系の伸長度の測定から逆算して貫入時間を決定した。各々の時 間の測定はすべて筆者らの常法(前諸報告)に従い，接種後の時間に対して各々の現象の％のカーブをつくりそ のカーブから時間を読みとった。葉柄（品種リシリ）を縦断した切断面細胞に切断 18 時間後に非親和性レースを 接種した。接種細胞(菌の侵入を受けた細胞)の 10 20\% で原形質流動は貫入後約 30 分で停止した $(20,25$, およ び $30 \mathrm{C}$ )。接種細胞の $50 \%$ では原形質流動は貫入後約 37 分 (20C) 40 分 (25C) 45 分 (30C) にそれぞれ停止した。 原形質流動停止から中性赤染色性そら失までの時間は 30 分 (20C) 10 分 $(25 \mathrm{C}), 10$ 分 (30C) であった。 